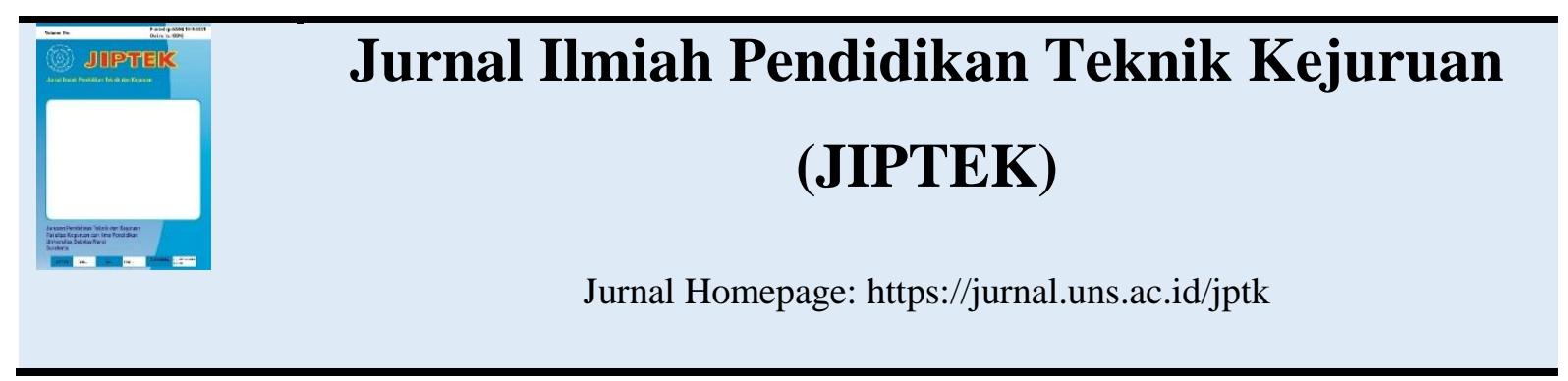

\title{
MENANAMKAN KONSEP PEMBELAJARAN BERBASIS STEAM (SCIENCE, TECHOLOGY, ENGINEERING, ART, AND MATHEMATHICS) PADA GURU-GURU SEKOLAH DASAR DI PACITAN
}

\author{
Yuyun Estriyanto ${ }^{1}$ \\ ${ }^{1}$ Program Studi Pendidikan Teknik Mesin, FKIP, Universitas Sebelas Maret Surakarta \\ Jalan Ahmad Yani 200 Surakarta \\ Email: yuyun.e@staff.uns.ac.id
}

\begin{abstract}
ABSTRAK
Artikel ini merupakan laporan dari program kemitraan masyarakat untuk menanamkan konsep pembelajaran berbasis STEAM (science, technology, engineering, art, and mathematics) bagi guru-guru Sekolah Dasar di Kabupaten Pacitan. Pembelajaran berbasis STEAM dipandang cocok dengan pembelajaran tematik SD karena sama-sama tidak dibatasi mata pelajaran secara kaku, melainkan merupakan integrase berbagai mata pelajaran yang dikemas menjadi satu tema sehingga bisa dilihat aspek keilmuan, teknologi, rekayasa, seni, dan matematika. Evaluasi kegiatan dilakukan dengan menggunakan angket. Diketahui bahwa setelah mengikuti pelatihan peserta memiliki antisuasme yang tinggi terhadap STEAM, kepahaman yang baik mengenai konsep pembelajaran berbasis STEAM, melihat kesesuaian dengan pembelajaran tematik di SD. Namun demikian, peserta masih memerlukan pendampingan lebih lanjut untuk mewujudkan dalam pemebelajaran.
\end{abstract}

Kata kunci: STEAM, pembelajaran tematik, kompetensi guru, SD, Pacitan

\begin{abstract}
This article is a report of a community partnership program to introduce STEAM-based learning concepts (science, technology, engineering, art, and mathematics) for elementary school teachers in Pacitan Regency. STEAM-based learning is seen to be compatible with elementary thematic learning because they are not rigidly restricted by subjects, but an integration of various subjects that are packaged into a topic that could be discussed in terms of scientific, technological, engineering, artistic, and mathematical. The evaluation of the program is carried out using a questionnaire. It is found that after attending the training, the participants have a high enthusiasm for STEAM, a good understanding of the STEAM-based learning concepts, and able to see the compatibility with thematic learning in elementary schools. However, the participants still need further assistance to realize the concepts into real learning.
\end{abstract}

Keywords: STEAM, thematic learning, teacher competency, elementary school, Pacitan

\section{PENDAHULUAN}

STEAM merupakan inovasi pembelajaran yang dimaksudkan untuk memberikan pengalaman belajar yang bermakna bagi siswa. STEAM merupakan singkatan dari science (ilmu), technology (teknologi), engineering (rekayasa), art (seni), and mathematics (matematika). Istilah ini mengacu pada sebuah pendekatan 
pembelajaran yang mengintegrasikan berbagai aspek tersebut ke dalam satu proses pembelajaran. Hal ini dimaksudkan untuk mendorong siswa berpikir kritis, menyeluruh, dan inovatif dalam merumuskan penyelesaian masalah. Seni turut serta diintegrasikan ke dalam pendekatan pembelajaran tersebut karena dianggap merupakan aspek yang ke depannya lebih berpengaruh dalam sisi kehidupan manusia, selain ilmu dan teknologi.

Model pembelajaran berbasis STEM merupakan inovasi pembelajaran yang berfokus ilmu (science), teknologi (technology), rekayasa (engineering), dan matematika (mathematics). Model ini merupakan sebuah terobosan pada di Amerika untuk mendorong inovasi karena ilmu dan teknologi merupakan kunci utama kemajuan pada saat itu. Belakangan, kata art (seni) ditamahkan menjadi STEAM oleh Georgette Yakman di Rhode Island School of Design karena menurutnya, ilmu dan teknologi dapat dimaknai dengan teknik dan seni dan semua itu mengandung unsur matematika (Riley, n.d.). Lebih jauh, pembelajaran berbasis STEAM kemudian dimaknai dengan pendekatan pembelajaran yang membantu terwujudnya experiental learning dan kemampuan menyelesaikan masalah yang dilandasi pada anggapan bahwa science, teknologi, rekayasa, seni, dan matematika adalah saling berhubungan. Hal ini juga senada dengan Maeda (2013) yang menambahkan art pada STEM menjadi STEAM karena percaya bahwa pada abad 21, desain dan seni lah yang akan mengubah perekonomian sebagaimana ilmu dan teknologi telah memerankannya pada abad-abad sebelumnya. Oleh karena itu, pendekatan
STEAM merupakan kesempatan besar untuk menyiapkan generasi yang siap dengan kondisi tersebut.

Mengacu pada Kamienski (2018), STEAM dapat dilakukan dengan: (1) mengidentifikasi aktifitas utama; (2) mengidentifikasi sub-aktifitas; mendefinisikan keuntungan khusus yang bisa diraih; (4) memilih matrik/mengembangkan pengambilan data; (5) mengeksplor aspek-aspek sosial yang terlibat; (6) mengeksplor kemanfaatan perseorangan. Dalam artikel online Binus (Uswah, 2019), komponen STEAM dirinci dengan lebih operasional, terdiri dari: (1) pemecahan masalah melalui inovasi dan desain; (2) keterkaitan antara asesmen, rencana belajar dan standar pembelajaran; (3) kombinasi lebih dari satu subjek dalam STEAM dan kegunaannya dalam seni; (4) lingkungan pembelajaran yang kolaboratif dan process based learning; dan (5) fokus pada hal - hal yang terjadi di kehidupan. Dengan kajian sistematis terhadap puluha literature, Thibaut (2018) menyimpulkan bahwa kerangka kerja (framework) STEM terdiri dari 5 hal, yaitu: (1) pengintegrasian konten STEM; (2) pembelajaran berbasis masalah; (3) pembelajaran berbasis inquiry; (4) pembelajaran berbasis desain; dan (5) pembelajaran kooperatif.

Dalam pembelajaran STEAM, tidak dikenal isolasi mata pelajaran. Ilmu dan teknologi dapat dimaknai melalui seni dan rekayasa, dan termasuk juga matematika. Masing-masing bidang ilmu saling menjelaskan satu dan yang lainnya. Sebuah permasalahan pembelajaran dipandang secara komperehensif lintas mata pelajaran dalam kurikulum (Long \& 
Davis, 2017). Perlu diingat juga oleh pada pendidik, pendekatan STEAM pada dasarnya merupakan pembelajaran berbasis penyelidikan (inquiry based) sehingga assessment tetap harus fokus pada ketercapaian ilmu atau keterampilan. Untuk mengetahui ketercapaian pengintegrasian art pada pada STEM maka dimanakah dan sejauh manakah kebermaknaan projek yang dikerjakan hendaknya menjadi yang utama (Radziwill et al., 2015).

Semangat yang dibawa pada pendekatan STEAM tersebut sejalan dengan pengimplementasian pembelajaran tematik di sekolah dasar (Wijaya et al., 2015). Pembelajaran tematik dimulai saat pengimplementasian Kuriulum 2013 khususnya bagi siswa kelas 1, 2, dan 3 Sekolah Dasar. Pembelajaran tematik merupakan pembelajaran yang berpusat pada siswa, mengintegrasikan beberapa mata pelajaran, memberikan pengalaman langsung kepada siswa, bersifat fleksibel, dan memberi kesempatan siswa berkembang sesuai dengan bakat minatnya (Sungkono, 2006). Dengan demikian, diharapkan pembelajaran dapat lebih menstimulus kemampuan mahasiswa untuk menghadapi tantangan abad 21 yang menuntut dimilikinya kompetensi 4C: creative, critical thinking, communicative, dan collaboration (Triyono, 2017).

Dari uraian tersebut, dapat disimpulkan bahwa pembelajaran berbasis STEAM sejalan dengan pembelajaran tematik yang dilaksanakan khususnya di Sekolah Dasar (SD) setelah diberlakukannya Kurikulum 2013 (Menteri Pendidikan dan Kebudayaan, 2013). Dalam pembelajaran tematik, pembelajaran tidak didasarkan pada mata pelajaran, melainkan dengan diberikan satu tema yang kemudian ditinjau dari dari sejumlah mata pelajaran. Dengan demikian, diharapkan lebih memberikan pengalaman belajar yang lebih bermakna kepada siswa. Hal ini sejalan dengan ruh pembelajaran berbasis STEAM. Oleh karena itu, kemampuan dan kesanggupan guru SD untuk mengintegrasikan STEAM ke dalam pembelajarannya diharapkan dapat lebih mengoptimalkan pengalaman belajar siswa. Artikel ini merupakan laporan program kemitraan masyarakat untuk menanamkan konsep pembelajaran berbasis STEAM bagi guru-guru SD di Kabupaten Pacitan oleh tim pengabdian masyarakat dari Universitas Sebelas Maret Surakarta.

\section{METODE}

Program kemitraan masyarakat untuk menanamkan konsep pembelajaran berbasis STEAM pada guru-guru SD di Kabupaten Pacitan ini merupakan representasi pendekatan penelitian tindakan siklus tunggal. Pelatihan STEAM menjadi inovasi yang diperkenalkan untuk meningkatkan kompetensi guru dalam mengintegrasikan pembelajaran berbasis STEAM dalam pembelajaran tematik di SD. Sasaran kegiatan adalah guru-guru SD di Kabupaten Pacitan. Peserta datang dari anggota KKG SD di kota Pacitan. Program terdiri dari pelatihan dan pendampingan penyusunan RPP dalam satu putaran. Pemahaman konsep pembelajaran berbasis STEAM diukur dengan menggunakan instrumen berbentuk angket dengan memanfaatkan fasilitas online form. Konsep pembelajaran berbasis STEAM pada 
peserta pelatihan dianggap sebagai satu konstruk yang dapat diukur dengan 12 indikator yang kemudian disusun menjadi item-item pertanyaan dalam angket berskala Likert. Data direkap dan disajikan secara deskriptif kuantitatif.

\section{HASIL DAN PEMBAHASAN}

Item pertanyaan dalam angket terdiri dari 12 butir sebagaimana disertakan pada Lampiran-1. Kedua belas butir angket tersebut merupakan penjabaran dari 4 aspek: (1) antusiasme peserta terhadap pelatihan, direpresentasikan oleh soal nomer 1, 2, dan 3; (3) penilaian peserta terhadap pelaksanaan pelatihan, dipresentasikan oleh soal nomer 4,5 , 6, dan 7; (3) persepsi peserta terhadap hasil pelatihan, direpresentasikan oleh nomer 8,9 , dan 10; dan (4) persepsi peserta terhadap kesesuaian materi pelatihan STEAM dengan pembelajaran di Sekolah Dasar, direpresentasikan oleh nomer 11 dan 12. Total diperoleh 36 umpan balik peserta yang mengisikan respond pada angket. Untuk masing-masing aspek, diperoleh hasil yang dapat direpresentasikan dalam bentuk pie chart sebagai disertakan pada Lampiran-2.

Antusiasme peserta pelatihan terhadap STEAM dapat dilihat pada aspek-1, 2, dan 3. Untuk aspek-1, 64\% peserta menyatakan setuju dan $28 \%$ menyatakan sangat setuju bahwa materi pelatihan mengenai STEAM merupakan pengetahuan yang baru bagi guru. Untuk aspek-

2, 69\% peserta menyatakan sangat setuju dan $31 \%$ menyatakan setuju bahwa pelatihan STEAM dapat menambah pengetahuan dan wawasan pedagogik bagi guru. Hal ini menunjukkan bahwa guru-guru SD di Kabupaten Pacitan memang membutuhkan pengetahuan tentang STEAM. Pengetahuan tentang STEAM dapat menambah pengetahuan dan wawasan pedagogik bagi guru. Dengan bertambahnya pengetahuan tersebut diharapkan guru memiliki lebih banyak alternatif model pembelajaran untuk diterapkan. Sejalan dengan aspek-1 dan 2, data untuk aspek-3 menunjukkan $50 \%$ peserta menyatakan setuju dan $47 \%$ menyetakan sangat setuju bahwa mereka tertarik dan antusias dalam mengikuti pelatihan pembelajaran berbasis STEAM. Hal ini menunjukkan bahwa mayoritas peserta memiliki antusiasme untuk mengikuti pelatihan karena mereka menganggap butuh dan materi tersebut merupakan materi baru.

Penilaian peserta terhadap pelaksanaan pelatihan dapat dilihat pada aspek-4, 5, 6, dan 7 . Pada aspek-4, 53\% peserta menyatakan sangat setuju dan $44 \%$ menyatakan setuju bahwa materi pelatihan pembelajaran berbasis STEAM menarik dan mudah untuk diikuti. Pada aspek-5, $69 \%$ peserta menyatakan setuju dan $25 \%$ menyatakan sangat setuju bahwa materi pelatihan telah sesuai dengan harapan peserta. Hal ini menunjukkan bahwa berdasarkan persepsi peserta setelah mengikuti kegiatan, pelatihan tersebut dinilai sudah berjalan dengan baik dan peserta memperoleh apa yang diharapkan dari pelatihan tersebut. Kepuasan peserta juga dapat dilihat pada aspek-6 dan 7 . Pada aspek-6, 61\% peserta menyatakan sangat setuju dan 36\% menyatakan setuju bahwa materi pelatihan pembelajaran berbasis STEAM dapat menunjang pekerjaan mereka. Sedangkan pada aspek-7, 50\% peserta menyatakan sangat setuju dan $47 \%$ menyatakan setuju bahwa pelatihan pembelajaran berbasis STEAM dapat 
meningkatkan kompetensi pedagogi para guru. Data tersebut memperkuat data pada aspek-5 bahwa peserta telah memperoleh apa yang diharapkan dari pelatihan tersebut, utamanya peningkatan kompetensi pedagogis dalam pengimplementasian STEAM dalam pembelajaran.

Persepsi peserta yang menggambarkan hasil pelatihan dapat dilihat pada aspek-8, 9, dan 10. Pada aspek-8, 67\% peserta menyatakan setuju dan 25\% menyatakan sangat setuju bahwa peserta menguasai materi pelatihan pembelajaran berbasis STEAM dengan baik setelah mendapatkan pelatihan Sedangkan pada aspek-9, 53\% peserta menyatakan setuju dan $14 \%$ menyatakan sangat setuju bahwa setelah mengikuti pelatihan, peserta dapat menyusun perangkat pembelajaran berbasis STEAM di kelas. Pada aspek ini, masih terdapat 25\% yang hanya memberikan pernyataan cukup setuju, bahkan ada $8 \%$ yang kurang setuju. Dari data ini terlihat masih ada $33 \%$ peserta yang kurang yakin telah mampu menyusun perangkat pembelajaran berbasis STEAM. Namun demikian, pada aspek-10, 68\% peserta menyatakan setuju dan $14 \%$ peserta menyatakan sangat setuju bahwa peserta dapat mengimplementasikan pembelajaran berbasis STEAM setelah pelatihan. Dengan demikian, bisa diinterpretasikan bahwa mayoritas peserta merasa sudah memahami konsep pembelajaran STEAM dengan baik, namun demikian peserta masih ragu apakah mereka bisa merealisasikan dalam bentuk perangkat pembelajaran. Akan tetapi, dengan penguasaan konsep tersebut peserta cukup optimis bahwa mereka akan bisa mewujudkannya.
Persepsi terkait dengan kesesuaian STEAM dengan pembelajaran SD dapat dilihat pada aspek-11 dan 12. Pada aspek-11, 53\% peserta menyatakan sangat setuju dan $44 \%$ peserta menyatakan setuju bahwa pembelajaran berbasis STEAM sesuai untuk diimplementasikan di SD. Pada aspek-12, 50\% peserta menyatakan sangat setuju dan $44 \%$ menyatakan setuju bahwa peserta didik akan tertarik dan antusias dalam mengikuti pembelajaran berbasis STEAM. Hal tersebut berarti bahwa setelah mengetahui konsepkonsep STEAM, para guru SD berpendapat bahwa pembelajaran cocok untuk diimplementasikan dengan pembelajaran SD dan pada siswa akan tertarik untuk mengikuti pendekatan pembelajaran tersebut.

Dari deskripsi data di atas, dapat diketahuui bahwa guru-guru SD memiliki antusiasme yang tinggi terhadap pelatihan berbasis STEAM karena dianggap sebagai kompetensi pedagogis yang baru dan sesuai dengan kebutuhan mereka dalam menjalankan tugas pembelajaran di SD. Sejauh persepsi peserta, peserta merasa mendapatkan apa yang diharapkan dengan mengikuti pelatihan tersebut. Materi pelatihan juga dinggap menarik dan menunjang pekerjaan mereka sebagai guru SD. Setelah mengikuti pelatihan, peserta merasa cukup yakin telah menguasai konsep pembelajaran berbasis STEAM, akan tetapi masih terdapat sejumlah besar peserta yang kurang yakin dapat mewujudkan dalam bentuk RPP. Namun pada prinsipnya, peserta setuju bahwa pembelajaran berbasis STEAM sesuai untuk untuk diterapkan dalam pembelajaran SD dan mereka mempunyai semangat untuk merealisasikannya. Hal ini juga 
menunjukkan bahwa masih diperlukan pendampainga lebih lanjut untuk merealisasikan dalam pembelajaran.

\section{SIMPULAN}

Dari uraian di atas dapat disimpulkan bahwa dari program kemitraan masyarakat yang berbentuk pelatihan pembelajaran berbasis STEAM pada guru-guru SD di Kabupaten Pacitan tersebut:

1. Dapat membentuk antusiasme yang tinggi pada guru-guru SD peserta pelatihan terhadap pembelajaran berbasis STEAM;

2. Dapat memberikan pemahaman yang baik megenai konsep pembelajaran STEAM pada guru SD yang terlibat dalam pelatihan dan hal tersebut sesuai dengan yang diharapkan oleh peserta;

3. Dapat menanamkan bahwa pembelajaran berbasis STEAM memiliki kecocokan untuk diintegrasikan dalam pembelajaran tematik SD; dan

4. Dapat memberikan pengetahuan dan keterampilan dasar pengimplementasian pembelajaran berbasis STEAM pada pembelajaran tematik SD namun masih memerlukan pendampingan lebih lanjut untuk merealisasikan dalam pembelajaran.

\section{DAFTAR PUSTAKA}

Kamienski, N., \& Radziwill, N. (2018). Design for STEAM: Creating Participatory Art with Purpose. The Steam Journal, 3(2). https://doi.org/10.5642/steam.20180302.0 8

Long, R., \& Davis, S. (2017). Using STEAM to Increase Engagement and Literacy Across Disciplines. The Steam Journal, 3(1). https://doi.org/10.5642/steam.20170301.0 7
Maeda, J. (2013). STEM + Art = STEAM. The Steam Journal, 1(1). https://doi.org/10.5642/steam.201301.34

Menteri Pendidikan dan Kebudayaan. (2013). Peraturan Menteri Pendidikan dan Kebudayaan RI No 67 Tahun 2013 tentang Kerangka Dasar dan Struktur Kurikulum SD/MI. Kementerian Pendidikan dan Kebudayaan RI.

Radziwill, N., Benton, M., \& Moellers, C. (2015). From STEM to STEAM:

Reframing What it Means to Learn. The Steam Journal, 2(1). https://doi.org/10.5642/steam.20150201.3

Riley, S. (n.d.). Getting Ready for Careers in STEAM. Retrieved September 22, 2019, from https://www.affordablecollegesonline.org/ college-resource-center/steam-careers-artschools/

Sungkono. (2006). Pembelajaran Tematik dan Implementasinya di Sekolah Dasar. Majalah Ilmiah Pembelajaran, 2(1), 5158. https://media.neliti.com/media/publication s/220102-pembelajaran-tematik-danimplementasinya.pdf

Thibaut, L., Ceuppens, S., De Loof, H., De Meester, J., Goovaerts, L., Struyf, A., Boeve-de Pauw, J., Dehaene, W., Deprez, J., De Cock, M., Hellinckx, L., Knipprath, H., Langie, G., Struyven, K., Van de Velde, D., Van Petegem, P., \& Depaepe, F. (2018). Integrated STEM Education: A Systematic Review of Instructional Practices in Secondary Education. European Journal of STEM Education, 3(1), 1-12. https://doi.org/10.20897/ejsteme/85525

Triyono, M. B. (2017). Tantangan Revolusi Industri ke 4 (i4.o) bagi Pendidikan Vokasi. Seminar Nasional Vokasi Dan Teknologi (Semnasvoktek), 1-5. http://eproceeding.undiksha.ac.id/index.ph p/semnasvoktek/article/download/653/495 I

Uswah. (2019). STEAM, Sebuah Pendekatan Pembelajaran Berbasis Seni. Articles. http://binus.ac.id/knowledge/2019/05/stea $\mathrm{m} /$

Wijaya, A. D., Karmila, N., \& Amalia, M. R. 
(2015). Implementasi Pembelajaran

Berbasis STEAM (Science, Technology,

Engineering, Art, Mathematics) Pada

Kurikulum Indonesia. Seminar Nasional 